„TURYZM”, t. 9, z. 2, 1999

Jolanta Wojciechowska

PROGRAM ZAJECĆ DYDAKTYCZNYCH Z PRZEDMIOTU „ORGANIZACJA TURYSTYKI W POLSCE I NA ŚWIECIE” NA STUDIACH Z GEOGRAFII TURYZMU I HOTELARSTWA NA UE

LE PROGRAMME DES ACTIVITÉS DIDACTIQUES AU SUJET „ORGANISATION DU TOURISME EN POLOGNE ET DANS LE MONDE" AUX ÉTUDES DE LA GÉOGRAPHIE DU TOURISME ET DE L'HÔTELLERIE À L'UNIVERSITÉ DE ŁÓDŹ

THE CURRICULUM OF THE 'ORGANIZATION OF TOURISM IN POLAND AND IN THE WORLD' SUBJECT AT THE GEOGRAPHY OF TOURISM AND HOTEL MANAGEMENT STUDIES AT THE UNIVERSITY OF LÓDŹ

Przedmiot jest prowadzony na $\mathrm{V}$ roku specjalności ,geografia turyzmu i hotelarstwa". Obejmuje 10 godz. wykładów i 10 godz. ćwiczeń, których tematyka jest komplementarna.

Zasadniczym celem przedmiotu jest pokazanie procesów kształtowania się różnych struktur organizacyjnych turystyki na świecie (głównie w krajach europejskich) i w Polsce, wraz z współczesnymi formami, typowymi cechami i osobliwościami.

Wykłady rozpoczynają się analizą pojęć typu: organizacja, struktura, system, model, po to aby w kolejnych cyklach ćwiczeń i wykładów wskazywać na strukturę bądź systemy czy modele organizacyjne turystyki wybranych państw. Analiza powyższych pojęć ma więc uświadomić, czym mają być rozważania o organizacji turystyki w Polsce i na świecie, w jakim stopniu będą to rozważania o strukturze, a kiedy o systemie.

Rozważania te wydają się być ciągle aktualne, zwłaszcza w obliczu wkraczania na międzynarodowy rynek turystyczny przy aktywnym poparciu swych rządów coraz to nowych krajów bądź regionów. Stąd układ problematyki wy- 
kładów ma na celu wpierw przedstawienie historycznego procesu formowania się struktury i systemów organizacyjnych turystyki, nastepnie na wykazaniu głównych ich cech i krystalizujących się tendencji rozwojowych, a w efekcie na zarysowaniu współczesnych modeli systemów organizacyjnych.

Chronologicznie więc omawiany jest rozwój form organizacyjnych turystyki. Wpierw ukazany jest historyczny zarys ich powstawania na świecie, głównie $w$ krajach europejskich, z podziałem na okresy do I wojny światowej i w okresie międzywojennym. W tym także uwzględnione są najważniejsze ówczesne międzynarodowe organizacje działające w zakresie turystyki, np. Międzynarodowa Liga Towarzystw Turystycznych, Międzynarodowa Federacja Automobilowa, Rada Centralna Turystyki Międzynarodowej, a także działalność Ligi Narodów w zakresie turystyki.

We wspomnianym okresie historycznym bliżej przedstawiana jest problematyka organizacji turystyki na ziemiach polskich pod zaborami oraz rozwój instytucji turystycznych i pierwszych organów administracji państwowej do spraw turystyki w Polsce międzywojennej. W zagadnieniu tym podkreślana jest specyfika sytuacji politycznej państwa polskiego oraz ukierunkowanie na społeczno-kulturową rolę turystyki.

W odniesieniu do okresu po II wojnie światowej, krótko przedstawiana jest organizacja turystyki na świecie, bliżej zaś zostaje zaprezentowany model organizacyjny w Polsce, wpierw w okresie ustroju socjalistycznego, a następnie w przygotowawczej fazie transformacji ustrojowo-systemowej, tj. w latach 1989 -1993. Więcej uwagi poświęca się okresowi po 1993 r., podkreślając najnowsze zmiany, osiagnięcia oraz porażki organizacyjne w zakresie turystyki w naszym kraju.

Końcowa problematyka wykładów ma na celu usystematyzowanie cech i trendów współczesnej organizacji turystyki w kontekście globalnym, tj. wybranych państw, regionów, jak i Polski. Cykl zagadnień zamykają rozważania nad ujęciem systemowym organizacji turystyki w świetle podstaw teoretycznych. Prezentowane tu są poglądy takich autorów, jak W. Reczek, R. Lazarek, A. Izydorczyk, W. Gaworecki, A. Kornak, M. Grabiszewski i L. Butowski.

Ćwiczenia rozpoczynają się od przedstawienia obecnej struktury organizacyjnej turystyki w Polsce na tle administracji państwowej i samorządowej. Na kolejnych ćwiczeniach wymagana jest aktywność studentów. Polega ona na samodzielnym wyszukaniu materiałów do określonego zadania (łacznie z dotarciem do przedstawicieli jednostek samorządowych branży turystycznej - np. do Izby Turystyki Ziemi Lódzkiej, oddziału Polskiej Izby Turystyki, PTTK czy Orbisu), następnie na ocenie uzyskanych materiałów, ich analizie i zreferowaniu.

Generalnie ćwiczenia koncentrują się na czterech zagadnieniach. Pierwsze z nich dotyczy charakterystyki współczesnych ważniejszych krajowych organizacji turystycznych i organizatorów turystyki, np: Polska Agencja Rozwoju Turystyki, Polska Izba Turystyki, regionalne izby turystyki, Polskie Towarzystwo 
Krajoznawczo-Turystyczne, Polskie Towarzystwo Schronisk Młodzieżowych, Polskie Stowarzyszenie Turystyki, Polski Związek Łowiecki, Polski Związek Żeglarski, Orbis SA, Państwowa Spółdzielnia Gromada i in. Po prezentacji struktury współczesnego pejzażu polskich organizacji i organizatorów turystyki do zadań studentów należy także próba pogrupowania i uporządkowania niniejszych organizacji. Następnie przedstawiane są w świetle literatury kryteria klasyfikacji.

Drugie zagadnienie dotyczy charakterystyki współczesnych ważniejszych międzynarodowych organizacji turystycznych oraz wybranych światowych liderów turoperatorów, jak: Światowa Organizacja Turystyki (WTO), Międzynarodowa Akademia Turystyki (AIT), Międzynarodowe Stowarzyszenie Turystyki (AIT), Międzynarodowa Federacja Schronisk Młodzieżowych (IYHF), ale także UNESCO, OECD oraz Club Mediterranee, Touristik Union International, Neckermann und Reisen, Carlson Companies Inc. Po prezentacji omawiane są funkcje międzynarodowych organizacji turystycznych oraz ich klasyfikacje.

Trzecie zagadnienie poświęcone jest przeglądowi rozwiązań organizacyjnych w zakresie turystyki w wybranych krajach. Najczęściej są to kraje o rozwiniętej gospodarce turystycznej, jak Francja, Hiszpania, Holandia, Irlandia, Grecja, Wielka Brytania, Austria, Szwecja, a także kraje zamorskie, jak USA, Japonia, Australia. Po prezentacji przedstawiane są grupy państw Europy Zachodniej podobnych do siebie pod względem statusu formalno-prawnego oraz źródeł finansowania w zakresie organizacji turystyki. Również omawiane są zadania państwowej administracji turystycznej w dziedzinie promocji i marketingu w wybranych państwach (wg badań WTO). Na koniec analizowane jest w świetle literatury pojęcie polityki turystycznej i jej formy (aktywna, pasywna).

Czwarte i ostatnie zagadnienie podejmowane na ćwiczeniach ma na celu zaprezentowanie przez studentów w świetle przeczytanej literatury cech oraz tendencji współczesnej organizacji turystyki w Polsce lub w innych krajach. Zadaniem studentów jest więc poszukanie i zanalizowanie artykułu z najnowszych źródeł nie tylko naukowych, ale także z zakresu społeczno-gospodarczego oraz branży turystycznej (m. in. „Rynek Turystyczny”, „Aktualności Turystyczne”, „Polska Gazeta Turystyczna”). Analiza artykułów nie może sprowadzać się do przedstawienia ich treści, lecz polegać powinna na wyszukaniu cech i tendencji charakterystycznych dla turystyki w kontekście kraju i świata. Wspólne ustalenie kluczowych cech zamyka cykl zagadnień podejmowanych na ćwiczeniach.

Podstawą zaliczenia ćwiczeń są wykonane przez studentów prace. Aby otrzymać ocenę dostateczna, student jest zobowiązany wykonać jedno zadanie, które polega na scharakteryzowaniu wybranej polskiej organizacji turystycznej głównie na podstawie dostępnej literatury. $\mathrm{Na}$ ocenę dobrą student wykonuje dwa zadania $w$ formie pisemnej oraz przygotowany jest do ich ustnej prezentacji. Pierwsze zadanie dotyczy charakterystyki wybranej organizacji turystycz- 
nej na świecie lub w Polsce (m. in. na podstawie wywiadów „u źródła”), ewentualnie charakterystyki organizacji turystyki w wybranym państwie. Drugie zadanie polega na pokazaniu najnowszych cech i tendencji właściwych dla organizacji turystyki w kraju i na świecie, opierając się na samodzielnie wyszukanych przykładach z literatury branżowej.

$\mathrm{Na}$ ocenę bardzo dobrą student zobowiązany jest, oprócz wykonania dwóch zadań zgodnie $\mathrm{z}$ wymaganiami na ocenę dobra, przystąpić do kolokwium z wykładów, przy czym nie może uzyskać z kolokwium oceny niższej od dobrej.

Podstawą zaliczenia wykładów są obecności. Dla studentów decydujących się na zaliczenie ćwiczeń na ocenę dostateczną wymagane są wszystkie obecności na wykładach. Dla ubiegających się o ocenę dobrą dozwolona jest jedna nieobecność, natomiast ocenę bardzo dobrą - dwie nieobecności.

\section{Literatura obowiązkowa}

B u tows k i L., 1998, Organizacja turystyki w Polsce. Przeglad struktur. Agencja Promocji Turystyki „Mart”, Warszawa.

B o r n e H., D o I i ń s k i A., 1998, Organizacja turystyki w Polsce, WSiP, Warszawa.

$\mathrm{L}$ a z a r e k R., 1972, Ekonomika i organizacja turystyki, PWE, Warszawa.

\section{Literatura uzupelniająca}

B a r R., D o I i ń s k i A., 1978, Turystyka, WSiP, Warszawa.

G a w o r e c k i W., 1998, Turystyka, PWE, Warszawa.

I z y d o r c z y k A., 1975, Organizacja turystyki w Polsce, Inst. Turystyki, Warszawa.

K o r n a k A. (red.), 1994, Zarzqdzanie turystykq, PWN, Warszawa.

K u I c z y c k i Z., 1977, Zarys historii turystyki w Polsce, SiT, Warszawa.

Ł a z a r e k R., 1967, Systemy organizacyjne turystyki. Studium porównawcze, „Ruch Turystyczny. Monografie", z. 3.

M e d 1 i k S., 1995, Leksykon podróży, turystyki, hotelarstwa, PWN. Warszawa.

Materiaty podstawowe z Kongresu Turystyki Polskiej, Warszawa, 6-8 listopada $1995 \mathrm{r}$.

M rów czyńska-Kozerska A., M erski J., 1995, Organizacja turystyki, WSE, Warszawa.

O s m a ń s k i E. J., 1982, Encyklopedia ONZ i stosunków międzynarodowych, WP, Warszawa.

R e c z e k W., 1977, Model organizacyjny turystyki w Polsce, SiT, Warszawa.

W o d e j k o S., 1987, Organizacja turystyki międzynarodowej, [w:] Ekonomika i organizacja turystyki, WSiP, Warszawa.

Czasopisma specjalistyczne: „Turyzm”, „Problemy Turystyki”, ,Ruch Turystyczny. Monografie”, „Rynek Turystyczny”, „Aktualności Turystyczne”, „Hotelarz”, „Polska Gazeta Turystyczna”.

Dr Jolanta Wojciechowska

Katedra Geografii Miast i Turyzmu

Uniwersytet Łódzki

ul. Kopcińskiego 31

90-142 Łódź
Wplynęło:

21 grudnia $1999 \mathrm{r}$. 